\title{
The Hidden Meaning in Hamasaki Ayumi's "Secret" Song Lyrics based on Riffaterre's Semiotics Analysis
}

\author{
Yustika Fatimatuzzahro Dewanti ${ }^{1}$ \\ Semarang, Indonesia
}

\begin{tabular}{|c|c|}
\hline Article History & Abstract \\
\hline $\begin{array}{l}\text { Submitted date: } \\
\text { 2021-11-21 } \\
\text { Accepted date: } \\
\text { 2021-11-25 } \\
\text { Published date: } \\
\text { 2021-11-30 } \\
\text { Keywords: } \\
\text { hidden meaning; } \\
\text { Hamasaki Ayumi; } \\
\text { semiotics of poetry; } \\
\text { Riffaterre }\end{array}$ & $\begin{array}{l}\text { There is always a hidden meaning in literary works, concise works like poetry. It is } \\
\text { always there even though it is not visible in the expression of its words. This is one of } \\
\text { the main factors that characterize poetry, a string of impressive, dense, and implied } \\
\text { meaning. This study attempts to describe the meaning contained in the lyrics of the } \\
\text { song Secret by Hamasaki Ayumi by using the semiotic theory of Riffaterre's poetry. In } \\
\text { this study, song lyrics are treated like poetry because of the similarity in form and } \\
\text { nature. The results of data analysis found that the main message to be conveyed by } \\
\text { the author is freedom. The author feels confined and bound by his status as a famous } \\
\text { artist. He feels that he does not have his world because his world belongs to the public. }\end{array}$ \\
\hline & Abstrak \\
\hline $\begin{array}{l}\text { Kata Kunci: } \\
\text { makna tersembunyi; } \\
\text { Hamasaki Ayumi; } \\
\text { semiotika puisi; Riffaterre }\end{array}$ & $\begin{array}{l}\text { Makna Tersembunyi yang Ingin Disampaikan Pengarang dalam Lagu Secret Karya } \\
\text { Hamasaki Ayumi Berdasarkan Analisis Semiotika Riffaterre } \\
\text { Selalu ada makna tersembunyi di dalam karya sastra, terutama karya pendek seperti } \\
\text { puisi. la selalu ada meskipun tidak nampak dalam ekspresi kata-katanya. Ini adalah } \\
\text { salah satu faktor utama yang menjadi ciri puisi, untaian kata-kata yang impresif, padat, } \\
\text { dan bermakna tersirat. Penelitian ini berusaha mendeskripsikan makna yang } \\
\text { terkandung dalam lirik lagu "Secret" karya Hamasaki Ayumi dengan menggunakan } \\
\text { teori semiotika puisi Riffaterre. Di dalam penelitian ini lirik lagu diperlakukan seperti } \\
\text { puisi karena kemiripan bentuk dan sifat lirik lagu. Dari hasil analisis data ditemukan } \\
\text { bahwa pesan utama yang ingin disampaikan oleh pengarang adalah kebebasan. } \\
\text { Pengarang merasa terkungkung dan terikat dengan statusnya sebagai artis terkenal. } \\
\text { la merasa tidak mempunyai dunianya sendiri karena dunianya menjadi milik publik. }\end{array}$ \\
\hline
\end{tabular}

\section{Pendahuluan}

Hamasaki Ayumi adalah salah satu artis penyanyi sekaligus pengarang lagu Jepang yang sangat terkenal pada era akhir tahun 1990-an sampai dengan awal tahun 2020-an. Ia diidolai bukan hanya karena musiknya yang bagus, tetapi juga karena pesan dalam lagunya yang menceritakan tentang kejujuran, perasaan, pengalaman, opini, dan kritiknya tentang kehidupan yang ia rasakan sendiri. Sebagian besar lagunya memang ditulis sendiri oleh Hamasaki.

Salah satu hal yang menarik dan menjadi salah satu yang melatarbelakangi penelitian ini adalah pernyataan Hamasaki Ayumi sebelum mengeluarkan album Secret bahwa ia mempunyai rahasia yang belum pernah diceritakan kepada publik dan akan disampaikan dalam salah satu lagunya yang

\section{Corresponding author:}

1 yustfade@gmail.com 
Dewanti, Y. F., (2021). The Hidden Meaning in Hamasaki Ayumi's "Secret" Song Lyrics based on Riffaterre's Semiotics Analysis. Japanese Research on Linguistics, Literature, and Culture 4 (1), 16-34. https://doi.org/10.33633/jr.v4i1.5435

berjudul "Secret" (Https://Ayumihamasaki. Fandom.Com/Wiki/Secret_Album, n.d.). Sebagai salah satu penggemar Hamasaki Ayumi, peneliti merasa penasaran dan tergugah untuk mengetahui apa rahasia yang diceritakan dalam lagu tersebut. Namun, setelah mendengarkan lagunya, ternyata pesan itu disampaikan dalam bahasa yang cukup sulit dipahami, sehingga dibutuhkan pemahaman yang mendalam dan komprehensif untuk memahami pesan yang terkandung dalam lagu.

Salah satu ancangan untuk memahami teks lirik lagu yang selama ini dikenal adalah dengan menggunakan teori semiotika. Semiotika adalah ilmu yang mempelajari tanda-tanda. Lirik lagu sebagai karya sastra, seperti halnya karya sastra lainnya banyak menggunakan tanda-tanda dalam penyampaiannya. Dalam penelitian ini, digunakan teori semiotika puisi Riffaterre untuk mengidentifikasi dan menganalisis makna yang terkandung di dalam lirik lagu "Secret". Teori Riffaterre mempunyai alat dan metode komprehensif yang dapat digunakan untuk menganalisis puisi yang kompleks sekalipun.

Pilihan terhadap teori ini dipandang tepat karena pada dasarnya lirik lagu adalah sama dengan puisi. Lirik lagu merupakan karya yang menggunakan bahasa tulis dengan pilihan diksi indah dan disajikan secara singkat dan padat, serta biasanya berisi ungkapan perasaan pengarangnya. Karakteristik lirik lagu jika dilihat dari sifat lirik lagu tersebut adalah sama dengan puisi. Seperti juga yang dikemukakan oleh Semi (1993), lirik dapat diartikan juga sebagai puisi yang dinyanyikan. Lirik lagu adalah serangkaian kata-kata yang disusun dan digunakan oleh seorang pencipta lagu untuk mengungkapkan ekspresi dan pikirannya dengan cara dituangkan ke dalam tulisan yang menyerupai sebuah puisi. Perbedaan antara lirik lagu dengan puisi adalah, lirik lagu menggunakan irama dan diiringi dengan melodi ataupun musik. Dengan kata lain, pada dasarnya lirik lagu adalah sama dengan puisi jika tidak dinyanyikan dan diiringi musik. Penelitian ini mengkaji lirik lagu sebagai puisi, dan oleh karenanya dikaji dengan ancangan semiotika puisi.

Penelitian sejenis sebelumnya tentang pemaknaan puisi dengan menggunakan teori Riffaterre dilakukan Santoso dan Wahyuningsih (2019). Mereka meneliti puisi Yogorecchimatta Kanashimini karya Nakahara Chuya melalui paradigma kualitatif dengan menggunakan teori yang sama dengan penelitian ini. Hasil penelitian mereka menyimpulkan bahwa matrik puisi adalah kesedihan mendalam yang dirasakan penyair dan modelnya adalah kesedihan yang kotor yang menjadi judul puisi. Penelitian tersebut juga menemukan tiga varian yaitu kesedihan membuat penyair hanyut dalam guyuran butiran salju, kesedihan membuat penyair putus asa, dan kesedihan membuat penyair tak berdaya. Dalam penelitian mereka studi intertekstual terhadap hipogram puisi tidak dilakukan sehingga tidak cukup komprehensif analisisnya.

Penelitian berikutnya yang lebih mirip adalah penelitian yang dilakukan oleh Noviana dan Saifudin (2020). Dengan menggunakan teori semiotika puisi Riffaterre mereka mengkaji makna lirik lagu anak Shabondama karya Ujo Noguchi. Penelitian keduanya menghasilkan temuan bahwa apa yang ingin disampaikan melalui lirik lagu Shabondama adalah sebuah ketidakberdayaan. Perbedaan dengan penelitian Noviana dan Saifudin hanya pada objek data yang dikaji, penelitian ini menggunakan data lirik lagu pop yang lebih kontemporer.

Tujuan penelitian mendeskripsikan makna atau pesan utama yang terkandung dalam lirik lagu "Secret" karya Hamasaki Ayumi berdasarkan analisis semiotika puisi Riffaterre. Kata semiotika berasal dari bahasa Yunani semeion yang berarti tanda, dengan demikian semiotika dapat diartikan sebagai ilmu yang mempelajari tanda. Semiotika adalah cabang ilmu yang berurusan dengan pengkajian tanda dan segala sesuatu yang berhubungan dengan tanda, seperti sistem tanda dan proses yang berlaku bagi penggunaan tanda (Van Zoest, 1993). Hoed (2011) menyatakan bahwa 
Dewanti, Y. F., (2021). The Hidden Meaning in Hamasaki Ayumi's "Secret" Song Lyrics based on Riffaterre's Semiotics Analysis. Japanese Research on Linguistics, Literature, and Culture 4 (1), 16-34. https://doi.org/10.33633/jr.v4i1.5435

semiotik adalah ilmu yang mengkaji tanda dalam kehidupan manusia. Tanda sendiri berarti sesuatu yang mewakili sesuatu yang lain (Noviana dan Saifudin, 2020).

Peletak dasar semiotika adalah dua orang yang hidup sezaman namun keduanya tidak saling mengenal dan tidak saling mempengaruhi, yakni Charles Sanders Peirce (1839-1914) dan Ferdinand de Saussure (1857-1913) (Nöth, 1990). Pierce adalah seorang ahli filsafat dari Amerika yang menyebut ilmu tanda sebagai semiotics, sementara Saussure berkebangsaan Prancis, seorang ahli bahasa dan menyebutnya sebagai semiology.

Dasar pengkajian ilmu tanda dari keduanya berbeda karena memang keduanya tidak saling mempengaruhi. Kajian semiotika Peirce didasarkan pada konsep triadic (trikotomi), yaitu representamen, interpretant, dan object. Representamen adalah tanda yang mewakili suatu objek tertentu, interpretant adalah makna tanda representamen yang berada dalam pikiran manusia, dan object adalah sesuatu yang diwakili oleh tanda atau representamen (Nöth, 1990). Peirce juga membagi kategori tanda menjadi tiga, yakni icon, index, dan symbol. Icon adalah tanda yang didasarkan pada kemiripan antara tanda dan obyek yang diwakilinya. Contoh icon adalah foto yang mewakili orang yang difoto tersebut. Index adalah merupakan tanda yang memiliki hubungan sebab-akibat dengan apa yang diwakilinya atau disebut juga tanda sebagai bukti. Contoh yang sering digunakan adalah asap sebagai index dari adanya api. Terakhir adalah symbol yang merupakan tanda yang maknanya bersifat konvensi atau kesepakatan bersama dalam budaya tertentu. Contoh dari symbol adalah warna merah sebagai simbol dari keberanian.

Sementara itu Saussure mendasarkan kajian semiologinya pada dua hal (diadic) yakni apa yang disebut signifié (signified/petanda) dan signifiant (signifier/penanda). Signifié atau petanda adalah konsep makna yang terdapat dalam pikiran manusia (sama dengan interpretant Peirce) dan significant (penanda) adalah citra bunyi yang menjadi tanda. Sebagai contoh adalah bunyi [k, e, $p$, a, I, a] merupakan penanda dari konsep atau petanda bagian tubuh manusia paling atas atau dapat juga bermakna pimpinan.

Kedua teori tentang semiotika tersebut sampai sekarang masih digunakan dan berkembang dalam bidang yang lebih luas. Bidang-bidang semiotika mencakup bidang budaya, sastra, linguistik, arsitek, multimedia, hukum, dan sebagainya.

Teori semiotika puisi Riffaterre $(1978,1983)$ menekankan pada penggunaan bahasa dalam karya sastra, terutama puisi. Bahasa yang digunakan dalam puisi berbeda dengan bahasa sehari-hari, dalam puisi pengarang menyampaikan maksudnya dengan tidak langsung atau berbeda dengan yang tertulis. Inilah yang menjadi dasar teori ini dalam mengkaji puisi. Menurutnya, ketidaklangsungan makna yang terdapat dalam puisi disebabkan oleh tiga hal, yakni displacing 'penggantian', distorting 'pembelokan', dan creating meaning 'penciptaan makna'. Penggantian makna terjadi ketika satu kata bukan mewakili makna harfiahnya melainkan mewakili makna yang lain, seperti yang terjadi pada fenomena metafora dan metonimi. Pembelokan makna disebabkan oleh penggunaan bahasa yang ambigu, kontradiksi, atau nonsense. Makna ambigu adalah makna yang tidak jelas, dapat dimaknai apapun sesuai pemahamannya. Ambiguitas ini akan memberi kesempatan kepada pembaca memaknai puisi di luar makna literalnya. Kontradiksi merupakan menyampaikan maksud secara berlawanan atau berkebalikan, seperti yang terjadi pada paradoks dan ironi. Nonsense merupakan bentuk kata-kata yang secara bahasa tidak bermakna karena diciptakan oleh pengarangnya dan bukan merupakan kata terdapat dalam kamus. Terakhir, penciptaan makna baru terjadi karena pengaturan organisasi teks yang menimbulkan nuansa atau makna baru. Pengaturan bentuk teks ini bukan dalam ruang lingkup bahasa. Contoh penciptaan 
Dewanti, Y. F., (2021). The Hidden Meaning in Hamasaki Ayumi's "Secret" Song Lyrics based on Riffaterre's Semiotics Analysis. Japanese Research on Linguistics, Literature, and Culture 4 (1), 16-34. https://doi.org/10.33633/jr.v4i1.5435

makna baru adalah bentuk simitri (keseimbangan), rima/ritme, enjambemen (perloncatan kesatuan sintaksis), serta persamaan posisi (homologues).

Selanjutnya Riffaterre (1978) juga menyatakan bahwa puisi adalah fenomena komunikasi dialektik antara teks dan pembacanya. Puisi adalah satuan yang utuh antara bentuk dan maknanya. Kesatuan keduanya adalah sebuah tanda semiotika yang harus ditafsirkan untuk dapat memaknai kandungan isi pesan puisi. Makna puisi hanya berasal dari bahasanya tetapi juga bentuknya. Proses yang dapat dilakukan pembaca dalam memahami teks puisi adalah dengan dua cara, yakni pembacaan heuristik dan pembacaan retroactive atau yang disebut hermeneutika.

- Pembacaan heuristik

Pembacaan heuristik menurut Riffaterre (1978) merupakan pembacaan tingkat pertama untuk memahami makna secara linguistik. Menurut Santosa (1993) pembacaan heuristik adalah pembacaan yang didasarkan pada konvensi bahasa yang bersifat mimetic (tiruan alam) dilakukan dengan membangun serangkaian arti yang heterogen, berserak-serakan, atau tak gramatikal. Sementara menurut Pradopo $(1999,2017)$ definisi pembacaan heuristik adalah pembacaan berdasarkan struktur bahasanya atau secara semiotik adalah berdasarkan konvensi sistem semiotik tingkat pertama. Pembacaan heuristik dilakukan dengan jalan menarasikan atau memparafrasakan unsur-unsur yang ada dalam puisi. Jika ada pola yang tidak teratur diatur kembali berdasarkan sistem bahasa yang berlaku. Dalam puisi seringkali tidak menggunakan grammar baku dan menghilangkan salah satu atau beberapa unsurnya. Masalah seperti inilah yang dibangun kembali dalam pembacaan heuristik. Hasil pembacaan heuristik adalah makna teks yang disebut oleh Riffaterre sebagai sistem semiotika tingkat pertama 'first order semiotics system' atau meminjam istilah Grice (1975) dalam ilmu pragmatik sebagai makna eksplikatur atau makna tuturan bukan makna yang 'dimaksudkan' oleh penuturnya

\section{- Pembacaan hermeneutik}

Riffaterre menyatakan bahwa pembacaan hermeneutik merupakan pembacaan tingkat kedua untuk menginterpretasi makna secara utuh. Pembacaan dilakukan secara berulang-ulang (retroactive) dan secara komprehensif mengkaitkan setiap unsur yang terdapat dalam puisi. Unsur puisi tidak hanya dimaknai secara literal seperti dalam pembacaan heuristik, namun juga dimaknai secara lebih luas menyangkut konotasi atau perluasan maknanya. Proses ini juga disebut proses decoding, yakni proses menafsirkan 'kejanggalan/ketidakgramatikalan' ataupun makna 'dibalik' teks yang ada dalam puisi. Dalam proses ini pembaca berupaya mencari makna 'yang dimaksudkan' yang biasanya terjadi sebagai dampak penggunaan ketidaklangsungan semantik pada bahasa yang digunakan dan bentuk-bentuk puisi ekspresi bahasa tidak langsung yang ditemukan pada proses pembacaan heuristik. Hasil pembacaan hermeneutik adalah pembaca dapat menemukan kesatuan makna puisi yang dibacanya.

- Matriks, model, dan varian

Matriks merupakan kata kunci yang menjadi gagasan utama dalam puisi. Riffaterre mengatakan bahwa matriks adalah ide dasar dalam menyusun puisi (1978: 12). Matriks dapat berupa satuan kebahasaan minimal dan bermakna harfiah, yakni dapat berupa kata, frasa, klausa, ataupun kalimat sederhana yang kemudian ditransformasikan ke dalam parafrasa yang lebih panjang, kompleks, dan tidak harfiah (1978: 19). Matriks kemudian diwujudkan dalam sebuah model yang nantinya dijabarkan dalam varian-varian sehingga membentuk keseluruhan teks puisi. Keberadaan matriks tidak ditemui dalam teks puisi, tetapi justru menjadi ruh utama dalam puisi. Seperti apa yang dikatakan oleh Riffaterre keberadaan matriks layaknya lubang kosong di tengah donat, tanpa 
Dewanti, Y. F., (2021). The Hidden Meaning in Hamasaki Ayumi's "Secret" Song Lyrics based on Riffaterre's Semiotics Analysis. Japanese Research on Linguistics, Literature, and Culture 4 (1), 16-34. https://doi.org/10.33633/jr.v4i1.5435

adanya lubang kosong di tengahnya tidak dapat disebut donat. Keberadaan matriks dapat diinterpretasikan melalui aktualisasinya berupa model, sebagai aktualisasi pertama, dan penjabarannya dalam bentuk varian-varian sebagai aktualisasi berikutnya. Model biasanya dapat ditemukan pada unsur puisi (kata, frasa, kalimat) yang sekiranya merepresentasikan matriks, biasanya berupa bahasa puitis yang menjadi pokok pembicaraan. Sementara varian adalah penjabaran-penjabaran yang menjelaskan modelnya.

\section{- Intertekstual hipogram}

Menurut Riffaterre, karya sastra hadir sebagai respon atas karya sastra yang lain, la tidak hadir secara serta merta. Karya sastra selalu berkaitan dengan teks lain yang menjadi latar belakang penciptaannya. Untuk itulah diperlukan kajian intertekstualitas dalam mengkaji karya sastra. Pemhaman yang komprehensif terhadap karya sastra hanya mungkin dilakukan oleh pembaca melalui interteks, yaitu dengan mengacu kepada teks-teks lain (Riffaterre, 1978:149), baik teks secara harafiah maupun teks dalam pengertian universal. Riffaterre menyebutnya dengan istilah hipogram. Sebuah istilah yang terinspirasi dari Saussure tentang paragram, yaitu sesuatu yang tersembunyi di balik kata-kata.

Keberadaan hipogram merupakan respon terhadap teks lain. Teks yang dimaksudkan di sini bukan hanya teks tertulis, namun juga mencakup teks lain seperti latar belakang kehidupan pengarang, kondisi sosial budaya saat karya sastra lahir, dan sebagainya. Seperti apa yang dikemukakan oleh Teeuw (1984) yang menyebutkan bahwa latar penciptaan karya sastra dapat meliputi masyarakat, peristiwa sejarah, kejadian alam, dan kehidupan. Hipogram pada dasarnya adalah matriks, yaitu sesuatu yang menjadi pusat makna yang mengisi ruang kosong dalam sebuah puisi. Oleh Riffaterre hipogram dikategorikan dalam dua jenis, yaitu hipogram potensial dan aktual. Hipogram potensial adalah hipogram yang aktualisasinya nampak dalam model dan varianvariannya dalam teks puisi atau dapat dikatakan sama dengan matriks. Sementara hipogram aktual adalah hipogram yang berupa teks-teks lain yang telah ada sebelumnya yang menjadi latar penciptaan teks baru.

\section{Metode Penelitian}

Sumber data penelitian diambil dari album kedelapan Hamasaki Ayumi yang berjudul Secret. Data berupa lirik lagu yang berjudul "Secret" dengan satuan data analisis berupa kata, frasa, klausa, kalimat, dan bait yang menyusun lirik lagu.

Dalam kajian pemaknaan puisi atau lirik lagu yang menggunakan teori semiotika Riffaterre, teknik pengumpulan data dan analisisnya dapat dijadikan satu karena data berupa keseluruhan lirik lagu sehingga tidak diperlukan lagi proses pengumpulan data. Data yang sudah ditentukan, yakni lirik lagu "Secret" kemudian disajikan beserta transliterasi dan terjemahannya dalam bahasa Indonesia. Adapun proses selanjutnya adalah sesuai dengan teori Riffaterre, yaitu:

1) Pembacaan heuristik bait per bait. Proses ini menghasilkan parafrasa dari bentuk bait lirik lagu menjadi kalimat-kalimat lengkap sehingga dapat lebih mudah dipahami secara bahasa.

2) Pembacaan hermeneutika. Proses ini menghasilkan pemahaman yang lebih komprehensif terhadap isi lirik lagu. Dari proses ini juga dapat diidentifikasi unsur-unsur ketidaklangsungan makna, matriks, model, dan varian puisi.

3) Analisis ketidaklangsungan makna dengan teori-teori yang diperlukan sesuai hasil identifikasi ketidaklangsungan makna. Ketidaklangsungan makna yang berupa metafora dan metonimi dianalisis berdasarkan metafora konseptual Lakoff dan Johnson. 

4) Analisis matriks, model, dan varian.
5) Kajian intertekstual hipogram lirik lagu.
6) Simpulan hasil analisis.

\section{Hasil dan Pembahasan}

\subsection{Lirik Lagu "Secret"}

Secret

\section{すれ違う少女達}

眩しくて目をそらした

無邪気なままの子供のような

自由な羽を持っていた

暗闇の向こう側

光射す場所を求め

ひとつ残った翼広げても

真実にだけ届かない

そこから見る私の姿は

どんな風に映っていますか

こんなこんないつわりだらけの

日々を笑い飛ばして下さい

手遅れになるその前に

飛ぶ事に疲れても

羽下ろす勇気もない

もしも願いが

ひとつ叶うなら

いっそここから連れ出して

今もここで私は変わらず

居場所をずっと探しています

どうかどうかあなたにだけは

この想いが伝わりますように

欲しい物など他にない... surechigau shoujotachi

mabushikute me wo sorashita

mujaki na mama no kodomo no youna

jiyuu na hane wo motte ita

kurayami no mukou gawa

hikarisasu bashou wo motome

hitotsu nokotta tsubasa hirogetemo

shinjitsu ni dake todokanai

soko kara miru watashi no sugata wa

donna fuu ni utsutte imasu ka?

konna konna itsuwari darake no

hibi wo warai tobashite kudasai

teokure ni naru sono mae ni

tobu koto ni tsukarete mo

haneorosu yuukimo nai

moshi mo negai ga

hitotsu kanau nara

isso koko kara tsuredashite

ima mo koko de watashi wa kawarazu

ibasho wo zutto sagashite imasu

douka douka anata ni dake wa

kono omoi ga tsutawarimasu you ni

hoshii mononado hokani nai

Terjemahan lirik:

Secret (Rahasia)

Berpapasan dengan gadis-gadis

Aku mengalihkan pandanganku karena silau

Seakan seperti anak kecil yang polos

Yang mempunyai sayap bebas

Di sisi lain dari kegelapan 
Dewanti, Y. F., (2021). The Hidden Meaning in Hamasaki Ayumi's "Secret" Song Lyrics based on Riffaterre's Semiotics Analysis. Japanese Research on Linguistics, Literature, and Culture 4 (1), 16-34. https://doi.org/10.33633/jr.v4i1.5435

\begin{abstract}
Aku mencari tempat di mana cahaya bersinar
Andai pun kukepakkan satu sayap yang tersisa

Kenyataan itu takkan tercapai
\end{abstract}

Dari tempatmu memandang sosokku

Bagaimana aku terlihat?

Ini semuanya tampak salah

Ketawakan saja aku sepuasnya

Sebelum terlambat

Bahkan saat aku lelah terbang

Aku tidak memiliki keberanian menurunkan sayap

Jika aku bisa memiliki permintaan

Satu saja untuk dikabulkan

Bawa segera aku pergi dari sini

Sekarangpun aku masih di sini belum berubah,

Masih selalu mencari tempat yang tepat

Setidaknya hanya kepadamulah

perasaan ini kusampaikan

Tidak ada keinginan lain

\title{
3.2 Pembacaan Heuristik
}

Pembacaan heuristik merupakan langkah awal dalam memaknai puisi. Dalam proses ini pembaca membaca keseluruhan lirik puisi atau lagu. Pembacaan ini harus sudah dengan pemahaman dan penguasaan yang baik akan bahasa yang digunakan, yang dalam hal ini adalah bahasa Jepang. Pembaca harus menguasai bunyi, cara baca, struktur, ataupun sistem bahasa Jepang. Proses pembacaan ini menghasilkan makna teks, yakni makna yang timbul berdasarkan kata-kata atau bahasa yang terdapat dalam lirik. Pemaknaannya bersifat harfiah atau yang disebut pemaknaan denotasi. Untuk dapat mencapai pemaknaan ini pembaca harus dapat menerjemahkan secara utuh kata-kata yang menyusun kalimat. Apabila terdapat susunan yang tidak sesuai dengan sistem, harus disusun ulang dengan susunan yang sesuai. Demikian pula jika terdapat kata atau unsur yang dihilangkan pembaca harus dapat mengidentifikasi dan mengembalikannya ke dalam kalimat asalnya.

Proses pembacaan dimulai dari pemaknaan judul yang dilanjutkan dengan pembacaan dan pemaknaan baris atau kalimat yang menyusun bait, dilanjutkan dengan pemaknaan bait yang menyusun lirik lagu secara keseluruhan.

\section{Judul}

Judul lirik diberi nama "Secret", merupakan istilah bahasa Inggris yang bermakna rahasia. Diksi yang digunakan sangat menarik karena dapat menimbulkan rasa ingin tahu yang besar dari pembacanya. Rahasia, merupakan sesuatu yang tidak semua orang mengetahuinya. la misterius dan orang akan bertanya-tanya tentang apa sebenarnya yang mau utarakan, rahasia apa yang akan diungkap dalam lirik lagu. 
Dewanti, Y. F., (2021). The Hidden Meaning in Hamasaki Ayumi's "Secret" Song Lyrics based on Riffaterre's Semiotics Analysis. Japanese Research on Linguistics, Literature, and Culture 4 (1), 16-34. https://doi.org/10.33633/jr.v4i1.5435

\section{Bait Pertama}

\author{
すれ違う少女達 \\ 眩しくて目をそらした \\ 無邪気なままの子供のような \\ 自由な羽を持っていた
}

Berpapasan dengan gadis-gadis

Aku mengalihkan pandanganku karena silau

Seakan (mereka) seperti anak kecil yang polos

Yang mempunyai sayap bebas

Di dalam bait pertama ini terdiri atas empat baris, yang kalau dicermati merupakan dua susunan kalimat. Baris pertama dan kedua merupakan satu kalimat dan demikian juga dengan baris ketiga dan keempat. Pada kedua kalimat tersebut subjek dilesapkan dan apabila dibuat kalimat yang lengkap adalah sebagai berikut.

"Aku mengalihkan mata karena silau ketika berpapasan dengan gadis-gadis. Karena aku melihat gadis-gadis itu mempunyai sayap bebas seperti anak kecil tanpa dosa."

Dari hasil pembacaan dan pemaknaan heuristik isi bait pertama mengandung pesan sebuah curahan hati pengarang tentang kondisi pribadinya yang "silau" saat melihat orang-orang atau gadis-gadis yang ditemuinya.

\section{Bait kedua \\ 暗闇の向こう側 \\ 光射す場所を求め \\ ひとつ残った翼広げても \\ 真実にだけ届かない}

Di sisi lain dari kegelapan

(Aku) mencari tempat di mana cahaya bersinar

Andai pun (ku)kepakkan satu sayap yang tersisa

Kenyataan itu takkan tercapai

Sama dengan bait pertama, bait kedua juga terdiri atas dua kalimat yang masih menceritakan kondisi pribadi pengarang. Subjek 'Aku' juga dilesapkan dalam bait ini. Dalam bait ini diceritakan pengarang yang mencari tempat "terang" yakni tempat di mana gadis-gadis yang dilihatnya berada, sementara dia berada dalam "kegelapan" dan hanya mempunyai satu "sayap" (tidak seperti sayap yang dipunyai oleh gadis-gadis yang dilihatnya).

Hasil pembacaan heuristik bait kedua adalah:

"Sementara aku yang berada di sisi lain dari gadisi-gadis itu, berada di tempat kegelapan. Aku mencari tempat yang bercahaya seperti tempatnya gadis-gadis itu. Tetapi sayangnya aku tidak mempunyai sayap seperti mereka, aku hanya mempunyai satu sayap, dan itu tidak akan cukup kuat untuk bias mencapai kebebasan seperti mereka."

\section{Bait ketiga}

$$
\begin{array}{ll}
\text { そこから見る私の姿は } & \text { Dari tempatmu memandang sosokku } \\
\text { どんな風に映っていますか } & \text { Bagaimana aku terlihat? } \\
\text { こんなこんないつわりだらけの } & \text { Ini semuanya tampak salah } \\
\text { 日々を笑い飛ばして下さい } & \text { Ketawakan saja aku sepuasnya } \\
\text { 手遅れになるその前に } & \text { Sebelum terlambat }
\end{array}
$$


Dewanti, Y. F., (2021). The Hidden Meaning in Hamasaki Ayumi's "Secret" Song Lyrics based on Riffaterre's Semiotics Analysis. Japanese Research on Linguistics, Literature, and Culture 4 (1), 16-34. https://doi.org/10.33633/jr.v4i1.5435

Pada bait ketiga terjadi komunikasi dengan pembaca. Ini dapat diidentifikasi dengan adanya bentuk tanya yang mempertanyakan kepada pembaca tentang pendapatnya mengenai diri pengarang. Pengarang juga mempersilakan pembaca untuk menertawakan kondisinya yang menurutnya memang patut ditertawakan. Hasil pembacaan heuristiknya adalah sebagai berikut.

"Aku bertanya kepadamu yang berada di tempat yang terang mengenai diriku yang berada di tempat kegelapan tentang bagai keadaanku. Bukankah aku menempuh kehidupan yang salah? Ketawakan saja aku sepuasnya, sebelum semuanya terlambat."

\section{Bait Keempat}

$$
\begin{aligned}
& \text { 飛ぶ事に疲れても } \\
& \text { 羽下ろす勇気もない } \\
& \text { もしも願いが } \\
& \text { ひとつ叶うなら } \\
& \text { いっそここから連れ出して }
\end{aligned}
$$

\author{
Bahkan saat aku lelah terbang \\ Aku tidak memiliki keberanian menurunkan sayap \\ Jika aku bisa memiliki permintaan \\ Satu saja untuk dikabulkan \\ Bawa segera aku pergi dari sini
}

Pada bait ketiga menceritakan kondisinya saat ini yang meskipun lelah "terbang" tidak berani berhenti "terbang". la hanya bisa meminta orang untuk membawanya pergi dari situasi yang dihadapi olehnya. Secara heuristik, bait ini dibaca:

"Kehidupanku ini semuanya salah. Bahkan saat aku lelah terbang, aku tidak berani menurunkan sayap untuk berhenti terbang. Seandainya saja aku boleh meminta kepadamu, satu saja permintaan yang kalau bisa kau penuhi. Tolong bawa aku pergi dari sini karena aku tidak kuat pergi sendiri."

\section{Bait kelima}

$$
\begin{array}{ll}
\text { 今もここで私は変わらず } & \text { Sekarangpun aku masih di sini belum berubah, } \\
\text { 居場所をずっと探しています } & \text { Masih selalu mencari tempat yang tepat } \\
\text { どうかどうかあなたにだけは } & \text { Setidaknya hanya kepadamulah } \\
\text { この想いが伝わりますように } & \text { perasaan ini kusampaikan } \\
\text { 欲しい物など他にない... } & \text { Tidak ada keinginan lain }
\end{array}
$$

Pada bait kelima yang mengakhiri lirik lagu nampak bahwa pengarang sampai saat ini masih berada pada kondisi yang sama, masih mencari jalan untuk menemukan tempat yang sesuai. Pengarang mengatakan bahwa ia hanya mempunyai satu keinginan saja yang melalui lirik lagu ini disampaikan kepada pembacanya.

"Sekarangpun aku masih berada di tempat yang sama. Masih tetap mencari tempat yang terang. Akan tetapi setidaknya aku sudah menyampaikan kepadamu. Satu-satunya keinginanku."

Hasil pembacaan tingkat pertama atau heuristik menunjukkan bahwa meskipun gambaran garis besar makna lirik lagu "Secret" dapat dipahami, belum secara utuh dipahami secara komprehensif. Hal itu disebabkan ada beberapa unsur yang menyusun bait mempunyai arti yang tidak sebenarnya. Secara garis besar isi lirik lagu ini merupakan curahan perasaan pengarang kepada pembacanya, tentang keinginannya untuk berpindah dari tempatnya sekarang. 
Dewanti, Y. F., (2021). The Hidden Meaning in Hamasaki Ayumi's "Secret" Song Lyrics based on Riffaterre's Semiotics Analysis. Japanese Research on Linguistics, Literature, and Culture 4 (1), 16-34. https://doi.org/10.33633/jr.v4i1.5435

\subsection{Pembacaan Hermeneutik}

Pada pembacaan tingkat kedua ini, diidentifikasi unsur-unsur lirik yang dalam pembacaan tingkat pertama belum dipahami. Pembacaan hermeneutik tidak hanya berdasarkan sistem bahasa saja, namun juga mendasarkan pada unsur-unsur di luar bahasa yang berpengaruh pada pemaknaan.

\section{Judul}

Secara konotasi diksi yang dipilih menjadi judul lirik, yakni "Secret" berkonotasi negatif karena pada umumnya istilah ini menunjukkan pada sesuatu yang disembunyikan yang tidak semua orang mengetahuinya. Pada umumnya sesuatu yang positif tidak akan dirahasiakan kecuali memang ditujukan untuk membuat kejutan. Dalam hal pesan lirik lagu ini, judul menjadi suatu rahasia yang ingin disampaikan oleh pengarangnya melalui lirik lagu secara keseluruhan.

\section{Bait Pertama}

$$
\begin{aligned}
& \text { すれ違う少女達 } \\
& \text { 眩しくて目をそらした } \\
& \text { 無邪気なままの子供のような } \\
& \text { 自由な羽を持っていた }
\end{aligned}
$$

Berpapasan dengan gadis-gadis

Aku mengalihkan pandanganku karena silau

Seakan (mereka) seperti anak kecil yang polos

Yang mempunyai sayap bebas

Hasil pembacaan hermeneutiknya adalah:

"Ketika aku melihat gadis-gadis atau orang-orang di sekitarku. Aku iri dengan keadaan mereka. Mereka seperti anak-anak kecil yang bisa bebas berbuat semaunya."

Di dalam isi bait ini dapat diketahui bahwa pengarang iri melihat orang-orang di sekitarnya yang mempunyai kebebasan yang tidak ia punyai.

\section{Bait Kedua}

$$
\begin{aligned}
& \text { 暗闇の向こう側 } \\
& \text { 光射す場所を求め } \\
& \text { ひとつ残った翼広げても } \\
& \text { 真実にだけ届かない }
\end{aligned}
$$

$$
\begin{aligned}
& \text { Di sisi lain dari kegelapan } \\
& \text { (Aku) mencari tempat di mana cahaya bersinar } \\
& \text { Andai pun (ku)kepakkan satu sayap yang tersisa } \\
& \text { Kenyataan itu takkan tercapai }
\end{aligned}
$$

Kemudian di dalam bait kedua yang merupakan lanjutan bait pertama. Pengarang masih menceritakan kondisinya yang tidak sesuai dengan harapannya. Berkebalikan dengan kondisi gadisgadis yang ditemui yang oleh pengarang disebut menyilaukan atau dipenuhi cahaya, pengarang merasa berada di kegelapan. la merasa pesimis karena untuk dapat meraih tempat yang bercahaya tidak cukup mempunyai kebebasan. Hasil pembacaan hermenutiknya adalah:

"Aku melihat dari sisi yang berkebalikan dengan orang-orang itu. Aku berada di tempat yang gelap sementara mereka berada di tempat yang terang. Aku ingin menemukan tempat yang terang, tetapi aku tidak mempunyai kebebasan untuk mencapainya."

Di dalam bait kedua ini pengarang membandingkan dirinya dengan gadis-gadis yang dilihatnya pada bait pertama. Pengarang merasa tidak berdaya untuk meraih keadaan ideal seperti yang dialami oleh gadis-gadis yang dilihatnya. Kaitan isi bait pertama dan kedua adalah sama-sama menceritakan curahan hati tentang keadaan diri pengarang. Pengarang menginginkan kehidupan 
Dewanti, Y. F., (2021). The Hidden Meaning in Hamasaki Ayumi's "Secret" Song Lyrics based on Riffaterre's Semiotics Analysis. Japanese Research on Linguistics, Literature, and Culture 4 (1), 16-34. https://doi.org/10.33633/jr.v4i1.5435

yang dialami gadis-gadis yang ditemuinya, sementara ia merasa pesimis meraih kehidupan yang sama karena ia merasa tidak berdaya meraihnya.

\title{
Bait Ketiga
}

$$
\begin{aligned}
& \text { そこから見る私の姿は } \\
& \text { どんな風に映っていますか } \\
& \text { こんなこんないつわりだらけの } \\
& \text { 日々を笑い飛ばして下さい } \\
& \text { 手遅れになるその前に }
\end{aligned}
$$

\author{
Dari tempatmu memandang sosokku \\ Bagaimana aku terlihat? \\ Ini semuanya tampak salah \\ Ketawakan saja aku sepuasnya \\ Sebelum terlambat
}

Hasil pembacaan hermeneutiknya:

"Dari tempatmu yang mempunyai kebebasan, bagaimana melihatku keadaanku yang tidak sepertimu? Ini semua tampak salah, karena kebanyakan orang melihat keadaanku yang enak, tetapi pada kenyataannya aku justru tidak mempunyai kebebasan. Ini adalah sesuatu yang ironis, jadi silakan saja kalau mau menertawakan keadaanku."

Di dalam bait ketiga pengarang tampak berkomunikasi dengan pembacanya. Ini dapat diidentifikasi dari bentuk pertanyaan pada baris kedua dan bentuk permintaan pada baris keempat. Tampak juga ada perubahan ragam bahasa yang digunakan. Di sini pengarang menggunakan bentuk sopan atau formal ketika berinteraksi dengan pembacanya, yakni ditandai dengan penggunaan bentuk -masu. Pengarang menanyakan pendapat pembaca tentang keadaannya dan mempersilakan pembacanya untuk menertawakan keadaan dirinya. Permintaan pengarang untuk menertawakan dirinya menimbulkan kejanggalan, normalnya dengan keadaan seperti diceritakan pada bait kedua, ia tidak akan meminta orang menertawakan. Orang justru akan bersimpati dan mungkin menaruh belas kasihan dengan keadaan yang dialami pengarang. Inilah yang mungkin menjadi salah satu rahasia yang disebutkan dalam judul. Ini berkaitan dengan keadaan sesungguhnya yang dialami pengarang, yakni Hamasaki Ayumi, seorang artis terkenal yang hidupnya justru banyak diidolakan orang. Selama ini orang beranggapan bahwa hidup seorang Hamasaki Ayumi adalah hidup yang sempurna yang diimpikan oleh banyak orang. Akan tetapi, ternyata justru ia lah yang menginginkan kehidupan orang biasa.

\section{Bait Keempat}

$$
\begin{aligned}
& \text { 飛ぶ事に疲れても } \\
& \text { 羽下ろす勇気もない } \\
& \text { もしも願いが } \\
& \text { ひとつ叶うなら } \\
& \text { いっここから連れ出して }
\end{aligned}
$$

\author{
Bahkan saat aku lelah terbang \\ Aku tidak memiliki keberanian menurunkan sayap \\ Jika aku bisa memiliki permintaan \\ Satu saja untuk dikabulkan \\ Bawa segera aku pergi dari sini
}

Pembacaan hermeneutik:

"Salah satu contoh kesalahan dalam kehidupanku adalah ketika aku lelahpun, aku masih harus terus bekerja. Aku tidak mempunyai keberanian untuk menghentikannya, karena menghentikan pekerjaan akan berdampak luas. Aku hanya bisa meminta pertolongan lewat lirik lagu ini, mohon bawalah aku pergi dari keadaan yang aku rasakan ini." 
Dewanti, Y. F., (2021). The Hidden Meaning in Hamasaki Ayumi's "Secret" Song Lyrics based on Riffaterre's Semiotics Analysis. Japanese Research on Linguistics, Literature, and Culture 4 (1), 16-34. https://doi.org/10.33633/jr.v4i1.5435

Di dalam bait ini, pengarang, yakni Hamasaki sudah mengisyaratkan ketidakberdayaannya atas keadaan yang ia rasakan. la merasa dieksploitasi dengan pekerjaannya. la merasa tidak mampu meninggalkan keadaan tersebut karena hanya memiliki satu sayap seperti yang diungkap dalam bait kedua. Ini adalah tentang kehidupan sesungguhnya pengarang, maka penggunaan kata 飛ぶ (tobu 'terbang') di sini berkaitan dengan aktifitas pekerjaan pengarang, yakni sebagai artis penyanyi. Sebagai artis, kehidupannya diatur oleh manajemen yang mengelola bisnisnya, yang pada kenyataannya bukan hanya bisnis saja yang dikelola melainkan juga hidupnya. Inilah yang membuatnya tidak bebas, bahkan untuk bias jalan-jalan sendiri saja tidak bias, ia selalu dijaga oleh body guardnya. Karena itu dalam baris terakhir ia minta tolong kepada pembaca untuk membawa serta ia pergi meninggalkan keadaan yang sekarang ia rasakan.

\section{Bait Kelima}

$$
\begin{aligned}
& \text { 今もここで私は変わらず } \\
& \text { 居場所をずっと探しています } \\
& \text { ぞうかどうかあなたにだけは } \\
& \text { この想いが伝わりますように } \\
& \text { 欲しい物など他にない... }
\end{aligned}
$$

Sekarangpun aku masih di sini belum berubah, Masih selalu mencari tempat yang tepat Setidaknya hanya kepadamulah perasaan ini kusampaikan

Tidak ada keinginan lain

\section{Pembacaan hermeneutik:}

"Sekarangpun aku masih berada pada keadaan yang sama, masih terikat pada pekerjaanku. Aku masih berusaha mencari keadaan yang lebih baik, yaitu mencapai kebebasan. Memang sulit untuk bisa tercapai, selama aku masih berprofesi sebagai artis. Akan tetapi, setidaknya aku sudah menyampaikan suatu rahasia, yakni tentang kehidupanku dan permintaanku untuk kebebasan."

Di dalam bait terakhir ini, Hamasaki, sebagai pengarang mengungkapkan bahwa keadaannya sampai lirik ini ditulis masih belum berubah. la masih berada di dalam kegelapan dan masih berusaha mencari tempat yang sesuai menurutnya. Meskipun usahanya belum berhasil, terdapat kelegaan di hati Hamasaki bahwa setidaknya ia sudah menyampaikan keinginannya kepada pembaca atau pendengar lagunya melalui lirik ini. Inilah sebenarnya rahasia dari apa yang ingin disampaikan oleh Hamasaki kepada para pembaca, pendengar, atau pun penggemarnya.

\subsection{Ketidaklangsungan Semantik (Makna)}

Berdasarkan pembacaan heuristik dan hermenutik diperoleh ungkapan-ungkapan yang maknanya tidak dapat dipahami secara literal. Berdasarkan identifikasi ketidaklangsungan makna dapat dikategorisasi sebagai berikut.

\subsubsection{Penggantian Makna}

Penggantian makna yang terjadi dalam lirik lagu adalah dalam bentuk metafora dan metonimi. Metafora dalam konsep modern dimaknai sebagai pemetaan dari domain sumber ke dalam domain target berdasarkan analogi atau kemiripan kedua domain (Kövecses, 2010; Lakoff \& Johnson, 1980; Noviana \& Saifudin, 2021; Saifudin, 2018; Swasono \& Saifudin, 2013). Sementara di dalam konsep tradisional, metafora dianggap sebagai bahasa kiasan yang mengumpamakan atau membandingkan satu hal ke hal yang lain (Saifudin, 2012; Swasono \& Saifudin, 2013). Kemudian metonimi adalah representasi sesuatu dengan menggunakan unsur yang terkait dengan sesuatu yang direpresentasikan. 
Dewanti, Y. F., (2021). The Hidden Meaning in Hamasaki Ayumi's "Secret" Song Lyrics based on Riffaterre's Semiotics Analysis. Japanese Research on Linguistics, Literature, and Culture 4 (1), 16-34. https://doi.org/10.33633/jr.v4i1.5435

Di dalam lirik lagu "Secret" ditemukan unsur-unsur metafora yakni hane, kurayami, hikarisasubasho, tsubasa, tobu, dan hane orosu.

- Hane: secara literal bermakna bulu atau sayap, yaitu organ tubuh burung atau serangga yang digunakan untuk terbang. Dalam Kokugojiten disebutkan arti hane adalah 鳥が空を飛ぶための器 官。翼 [tori ga sora o tobu tame no kikan. Tsubasa 'organ burung yang digunakan untuk terbang ke angkasa. Sayap'] Dalam bahasa puisi, kata sayap sering dimaknai sebagai alat untuk mencapai kebebasan karena terbang adalah lambang kebebasan. Burung dapat terbang ke manapun tanpa dibatasi batasan gravitasi. Makhluk lain seperti manusia dan binatang yang tidak bersayap hanya dapat berjalan atau bergerak di atas tanah dan gerakannya jelas lebih terbatas dari pada burung yang dapat terbang. Dengan demikian kata sayap atau hane dalam lirik ini dapat dimaknai sebagai alat kebebasan. Secara metaforis, domain sayap di sini adalah sebagai domain sumber dengan domain target kemampuan. Metafora yang terbentuk adalah KEMAMPUAN ADALAH SAYAP. Pemetaan metafora ini berdasarkan analogi bahwa sayap adalah alat untuk terbang dan kalau tidak mempunyai sayap berarti tidak mampu terbang.

- Kurayami: secara literal berarti kegelapan. Dalam Kokugojiten diartikan まったく光がなく、 暗いこと (kegelapan, sama sekali tidak ada cahaya). Kegelapan mempunyai konotasi yang negatif dan merupakan negasi dari terang atau cahaya. Makna metafora dari kegelapan adalah tiadanya harapan atau prospek masa depan. Domain sumber adalah kegelapan dan domain targetnya tiada harapan. Metafora yang terbentuk adalah TIDAK ADA HARAPAN ADALAH KEGELAPAN. Pemetaan antara domain sumber dan target berdasarkan analogi bahwa di dalam gelap orang tidak dapat melihat apapun, apa yang ada di depan matanya juga tidak terlihat. Sama dengan situasi orang yang tidak bisa melihat masa depannya.

- Hikarisasubasho: Secara literal bermakna tempat yang menunjukkan cahaya. Metafora ini kebalikan dari metafora sebelumnya yaitu kurayami, sehingga metafora yang terbentuk adalah ADA HARAPAN/PROSPEK ADALAH CAHAYA.

- Tsubasa: makna tsubasa adalah sayap, hampir sama dengan hane. Beda keduanya kalau tsubasa lebih mengacu pada sepasang sayap sebagai organ burung untuk terbang, hane lebih mengacu pada bulu-bulu yang menyusun (biasanya dalam penyebutan hane tidak disertai kata sepasang). Oleh karena mempunyai arti yang sama dengan hane maka makna metaforanya juga sama dengan hane.

- Tobu: menurut Kokugojiten berarti: 空中を移動する(kuuchuu wo idoo suru 'bergerak di udara'), atau sama saja dengan terbang, seperti yang dilakukan oleh burung. Terbang sebenarnya mempunyai konotasi positif meskipun dalam konteks tertentu dapat berkonotasi negatif, seperti dalam penggunaan kata terbang untuk menunjukkan sesuatu yang hilang. Terbang juga dapat dimaknai sebagai kebebasan sebagaimana layaknya burung yang bebas terbang ke manapun. Di dalam konteks ini, terbang menunjukkan arti sebagai aktifitas Hamasaki sebagai seorang penyanyi di dunia hiburan. Aktifitas utama burung adalah terbang, seperti halnya dikenal aktifitas cecak merayap, ikan berenang, ataupun kodok melompat. Di dalam metafora dikenal metafora orientasi yang memberikan penilaian positif atau negatif atas sesuatu berdasarkan orientasi lokasi. Sebagai contoh adalah penilaian atas adalah baik, bawah adalah buruk; kanan baik dan kiri buruk, dan seterusnya. Secara orientasi terbang adalah aktifitas yang berada di atas yang berarti baik karena metafora ATAS ADALAH BAIK; BAWAH ADALAH BURUK. Dengan begitu terbang adalah aktifitas 
Dewanti, Y. F., (2021). The Hidden Meaning in Hamasaki Ayumi's "Secret" Song Lyrics based on Riffaterre's Semiotics Analysis. Japanese Research on Linguistics, Literature, and Culture 4 (1), 16-34. https://doi.org/10.33633/jr.v4i1.5435

pekerjaan yang baik yang diidam-idamkan oleh orang banyak. Aktifitas terbang tidak tepat jika mewakili pekerjaan yang citranya kurang baik dan tidak diidamkan oleh orang, seperti penggali kubur, penagih utang, maupun buruh kasar. Metafora yang terbentuk di sini adalah AKTIFITAS/PEKERJAAN IDAMAN ADALAH TERBANG.

- Haneorosu: secara literal bermakna menurunkan sayap (berhenti mengepakkan sayap). Dalam konteks pada bait keempat dapat bermakna menghentikan aktifitas, yang dalam hal ini adalah aktifitas menyanyi. Representasi makna yang ada dalam metafora ini adalah orientasi karena verba orosu berhubungan dengan orentasi turun. Metafora yang terbentuk adalah MENURUNKAN ADALAH BERHENTI dan MENAIKKAN ADALAH AKTIFITAS.

Metonimi yang dapat diidentifikasi dalam lirik lagu "Secret" adalah: shoujotachi, me, hane, dan koko.

- 少女達 (shoujotachi) adalah metonimi atau representasi orang-orang. Bukan hanya gadisgadis saja namun keseluruhan orang yang dilihat pengarang atau penyanyi, khususnya para fans yang menonton atau mendengarkan lagunya.

- 目 (me) secara literal berarti mata. Dalam bait pertama 目 menjadi unsur idiom dalam 目を そらした。Makna literal dari idiom ini adalah mengalihkan mata yang dalam hal ini sebenarnya bukan mata yang dialihkan, melainkan pandangan. Jadi di sini mata adalah metonimi dari pandangan.

- 羽 (hane) dalam 羽降ろす (haneorosu) juga merupakan metonimi, hane di sini merepresentasikan terbang atau tobu. Sebenarnya hane hanya merupakan alat atau organ untuk terbang.

- そこ (soko 'di situ') pada baris pertama bait ketiga dan ここ (koko 'di sini') dalam baris pertama bait kelima merupakan representasi dari keadaan bukan hanya tempat, yakni meliputi keadaan, koko adalah keadaan yang dirasakan dan yang ada yang dialami pengarang, sementara soko adalah keadaan pembaca/pendengar yang diajak komunikasi.

\subsubsection{Pembelokan Makna}

Menurut Riffaterre pembelokan makna terjadi karena tiga hal, yaitu ambiguitas, kontradiksi, dan nonsense. Ambiguitas adalah ungkapan-ungkapan multitafsir, bermakna ganda. Kemudian kontradiksi berarti mengandung pertentangan, seperti paradoks atau ironi. Sementara nonsense adalah kata-kata yang secara bahasa tidak bermakna, tidak terdapat di dalam kamus, dan hanya berupa susunan bunyi.

Ambiguitas adalah sesuatu keniscayaan dalam karya sastra karena bahasa yang digunakan bukan bahasa sehari-hari, lebih-lebih dalam bahasa puisi. Bahasa puisi maupun lirik lagu banyak menggunakan ungkapan yang bermakna ganda. Hasil identifikasi ambiguitas di dalam lirik lagu ini adalah sebagai berikut.

- 眩しくて目をそらした(mabushikute me wo sorashita): mabushii merupakan kata sifat yang berarti menyilaukan dan me wo sorashita adalah idiom yang berarti mengalihkan pandangan. Namun dalam hal ini keseluruhan klausa ini bermakna iri, iri dengan keadaan yang dimiliki oleh orang-orang yang ditemuinya. 
Dewanti, Y. F., (2021). The Hidden Meaning in Hamasaki Ayumi's "Secret" Song Lyrics based on Riffaterre's Semiotics Analysis. Japanese Research on Linguistics, Literature, and Culture 4 (1), 16-34. https://doi.org/10.33633/jr.v4i1.5435

一無邪気なままの子供のような自由な羽を持っていた: kalimat ini berarti mempunyai sayap bebas layaknya anak kecil yang tiada dosa. Dari analisis makna kalimat ini diketahui bahwa maksud kalimat ini adalah memiliki kebebasan, namun perumpamaan yang digunakan adalah mempunyai sayap seperti anak kecil. Perumpamaan seperti ini menjadi multitafsir, karena sayap sebenarnya tidak dimiliki oleh anak kecil, tetapi oleh burung atau serangga.

Kemudian dalam hal kontradiksi, yaitu pertentangan makna, di dalam lirik lagu tersebut terdapat ironi. Ironi adalah semacam sindiran terhadap suatu keadaan yang diungkapkan secara berkebalikan. Ini nampak pada bait ketiga ketika pengarang meminta pembacanya menertawakan keadaan pengarang dengan ungkapan 日々を笑い飛ばして下さい(hibi wo warai tobashite kudasai 'tertawalah sepuasnya'). Dengan keadaan yang dialami pengarang seharusnya ungkapan simpatilah yang lebih sesuai, bukan menertawakan.

Untuk hal terakhir dalam pembelokan makna, yaitu nonsense tidak ditemukan dalam lirik lagu "Secret".

\subsubsection{Penciptaan Makna}

Bagaimanapun antara lirik lagu dan puisi tetap terdapat perbedaan. Lirik lagu disampaikan dalam bentuk nyanyian dan puisi pada umumnya disampaikan dengan cara pembacaan. Selain itu, bentuk penyajianpun seringkali berbeda. Pada lirik lagu biasanya hanya ditulis perbait tanpa ada variasi yang kompleks. Dalam penyajian puisi lebih variatif, baik dari bentuk, susunan kata, bunyi, maupun suku katanya. Bentuk-bentuk penyajian puisi yang variatif tersebut tentunya menciptakan arti tersendiri. Dalam lirik lagu, penciptaan makna biasanya berupa tambahan bunyi yang disuarakan dengan nada tertentu, seperti du du du, dan sebagainya. Dalam lirik lagu "Secret" tidak ditemukan hal semacam itu. Penciptaan makna yang dapat diidentifikasi adalah pengorganisasian jumlah baris dalam bait, dalam bait pertama dan kedua berjumlah empat dan dalam bait ketiga sampai lima berjumlah lima. Perbedaan jumlah baris tersebut ternyata menciptakan makna tertentu, pada bait yang berjumlah empat merupakan curahan perasaannya sendiri, sementara pada bait yang berjumlah lima baris merupakan interaksi komunikasi dengan pembaca.

\subsection{Matriks, Model, dan Varian}

Dari hasil identifikasi pembacaan heuristik, hermeneutik, dan analisis ketidaklangsungan semantik dapat diketahui bahwa pesan utama yang ingin disampaikan oleh pengarang dalam lirik lagu "Secret" adalah keinginan pengarang untuk bebas dari keterikatan-keterikatan sebagai konsekuensi atas keterkenalan dirinya sebagai artis populer. Di balik kehidupannya yang oleh orang lain dinilai glamour, mewah, dan semua kenginannya dapat terpenuhi, namun ternyata pengarang tidak mempunyai kebebasan seperti layaknya orang biasa. Kebebasan inilah yang diinginkan oleh pengarang yang disampaikan melalui lirik lagu. Judul lagu "Secret" adalah gambaran di balik kehidupan artis yang ternyata sangat terikat dengan aturan. Hidupnya sudah diatur oleh manajemen yang mengurus bisnisnya. Bahkan untuk pergi sendiri saja tidak bisa karena harus dikawal oleh body guardnya. Dengan demikian dapat disimpulkan bahwa matriks lirik lagu ini adalah kebebasan yang diinginkan oleh pengarang.

Model dari matriks tentang keinginan bebas seperti disebutkan dalam paragraf sebelumnya dapat dilihat dari isi lirik lagu. Demikian juga dengan varian yang menjadi penjabaran dari model. Model yang merupakan cerminan dari matrik tentang keinginan untuk bebas terdapat dalam kata dan frasa jiyuuna hane 'sayap kebebasan', tsubasa 'sayap', tobu 'terbang', dan hoshii mono 'keinginan'. Semua model tersebut adalah representasi dari keinginan bebas dari pengarangnya. 
Dewanti, Y. F., (2021). The Hidden Meaning in Hamasaki Ayumi's "Secret" Song Lyrics based on Riffaterre's Semiotics Analysis. Japanese Research on Linguistics, Literature, and Culture 4 (1), 16-34. https://doi.org/10.33633/jr.v4i1.5435

Sementara penjabaran yang lebih jelas disebutkan dalam varian tentang rasa iri pengarang kepada para penggemar atau orang biasa yang bisa bebas, tentang keadaannya yang berada pada kegelapan yang tidak bisa mencapai tempat terang, tentang ketidakberaniannya dalam menghentikan kepakan sayapnya, dan tentang perasaan pesimisnya terhadap keinginannya.

\subsection{Interteks Hipogram}

Riffaterre menyebutkan bahwa hipogram terbagi dua, yaitu hipogram aktual dan potensial. Hipogram aktual adalah latar belakang penciptaan lirik lagu yang berasal dari 'teks' lain. Hipogram aktual diperoleh dari studi interteks terhadap teks-teks lain yang menjadi latar penciptaan teks yang dikarang. Teks yang dimaksud bukan hanya teks tertulis, yakni karya-karya lain (puisi/lirik lagu), teks lain seperti kehidupan pengarang juga bisa menjadi latar belakang penulisan teks.

Hipogram potensial pada dasarnya adalah matriks, yakni gagasan utama penciptaan puisi/lirik yang tidak tertulis di teks, namun dijabarkan di dalam puisi/lirik lagu melalui model dan variannya. Hipogram potensial atau matriks dari lirik lagu ini adalah keinginan untuk bebas. Apa yang dimaksud dengan "Secret" sebagai judul lirik adalah bahwa sesungguhnya menjalani kehidupan sebagai artis tidak seperti penampakannya yang serba ideal, mewah, dan tercukupi. Di balik semua yang nampak, ternyata ada keterikatan yang membuat artis tidak mempunyai kebebasan. la seakan tidak mempunyai dirinya sendiri, karena ia sudah menjadi milik masyarakat.

Hipogram aktual dari lirik lagu yang "Secret" ini dapat diidentifikasi dengan melihat teks-teks lain yang dibuat sebelumnya atau pada masa yang sama, dan juga teks kehidupan pengarang. Mengingat teks lirik lagu "Secret" dibuat sebagai salah satu lirik lagu dalam album lagu Hamasaki Ayumi yang juga berjudul "Secret", pada tahun 2006, hipogram aktualnya diambil dari beberapa judul lirik lagu yang terdapat dalam album tersebut.

Secret (秘密の) adalah album studio kedelapan Hamasaki Ayumi yang dirilis pada 29 November 2006 oleh Avex Trax. Seperti semua karya sebelumnya, Hamasaki menulis semua lirik di album Secret. Komposisi album sebagian besar ditangani oleh Dai Nagao dan Tetsuya Yukumi, keduanya sering berkolaborasi dengan Hamasaki. Umumnya album yang dipengaruhi pop-rock, Hamasaki mengatakan bahwa arti dari album itu sendiri adalah sebuah rahasia, dan di album ini ia menceritakan rahasia yang dia simpan tentang dirinya yang tidak diketahui publik (https://ayumihamasaki. fandom.com/wiki/Secret_Album). Di dalam album ini terdapat 14 lagu (dua lagu instrumentalia), dan "Secret" adalah lagu yang ditempatkan pada posisi terakhir atau keempat belas.

Lirik lagu pertama berjudul "Not yet", yang berisi pesan tentang rahasia yang belum diberitahukan kepada pembacanya. Isi lagu ini seolah sebagai pengantar menuju sebuah rahasia yang akan disampaikan oleh pengarang. Lirik lagu kedua berjudul "Until that day", yang menceritakan keinginannya pada suatu saat untuk mengubah hidupnya. Kemudian pada lagu ketiga yang berjudul "Startin", menceritakan pengarang yang mulai bermimpi untuk bisa jujur kepada dirinya sendiri, dan pada lagu selanjutnya yang berjudul "1 love", pengarang menyatakan bahwa ia adalah orang yang punya pendirian sendiri dan hidupnya tidak tergantung pada orang lain. Pada lagu yang berjudul "It was", pengarang menyampaikan pesan agar selalu jangan menyerah dalam upaya memperjuangkan hidup. Setelah diselingi musik instrumentalia berjudul "Labyrinth", dilanjutkan ke lagu "Jewel" yang menyampaikan pesan tentang selalu adanya kebaikan dalam situasi apapun. Lagu berjudul Momentum bercerita tentang penyesalan di masa lalu yang tidak berbuat banyak hal dan dilanjutkan dengan lagu instrumentalia berjudul "Taskinst". Kemudian lagu ke-10 yang berjudul "Born to be" menyuarakan semangat kebebasan. "Beautiful Fighters", "Blue Bird", 
Dewanti, Y. F., (2021). The Hidden Meaning in Hamasaki Ayumi's "Secret" Song Lyrics based on Riffaterre's Semiotics Analysis. Japanese Research on Linguistics, Literature, and Culture 4 (1), 16-34. https://doi.org/10.33633/jr.v4i1.5435

dan "Kiss o' kill" sebagai tiga lagu terakhir sebelum "Secret" mengungkapkan pesan yang senada, yakni tentang perjuangan, penerimaan, kejujuran, dan optimisme, meskipun juga terdapat nuansa kesedihan karena kenyataan apa yang menimpa diri seseorang tidak selalu sama dengan apa yang diinginkan.

Dari pesan lagu-lagu yang terdapat di dalam album tersebut, nampak menjadi hipogram bagi isi lirik lagu "Secret". Lirik lagu-lagu tersebut menjadi persiapan dan langkah-langkah menuju pesan lagu terakhir, yakni "Secret". Pesan itu dimulai dari adanya rahasia yang akan diungkap, pentingnya memahami diri sendiri, perjuangan dan semangat pantang menyerah dalam menggapai tujuan, serta pada akhirnya mengungkapkan secara jujur tentang apa yang dialami dan keinginan untuk meraih kebebasan dalam hidup. Dengan demikian dapat dikatakan bahwa hipogram aktual dari "Secret" adalah lagu-lagu yang terdapat dalam album yang sama.

Teks lain yang menjadi hipogram lirik lagu "Secret" adalah teks kehidupan pengarang, yakni latar belakang kehidupan dari Hamasaki Ayumi. Di dalam isi bab kedua sudah dipaparkan bahwa masamasa akhir tahun 1990-an dan selama kira-kira satu dekade beikurnya adalah masa keemasan dari seorang Hamasaki Ayumi. la adalah artis wanita paling popular di Jepang. Hampir setiap tahun sejak tahun 1998 ia memperoleh penghargaan, bahkan ia sempat menolak penghargaan yang diberikan kepadanya dengan alasan untuk memberikan kesempatan kepada artis lain yang berbakat juga. la juga menjalankan banyak bisnis. Konsekuensi dari kepopularannya sebagai artis serta kesibukannya dalam berbagai bidang adalah hilangnya kebebasan dirinya. Sosok keberadaannya sudah menjadi milik masyarakat sehingga seolah ia tidak bisa memiliki dirinya sendiri. Inilah sebenarnya rahasia yang ingin diungkap oleh Hamasaki terkait kehidupannya yang oleh banyak orang dianggap enak ternyata di balik itu Hamasaki justru menginginkan kehidupan yang dimiliki orang biasa. la menginginkan kebebasan yang tidak ia miliki karena statusnya. Inilah yang menjadi matriks atau inti dari pesan atau makna lirik lagu "Secret", yaitu keinginan akan kebebasan.

\section{Simpulan}

Dari hasil analisis dan dilengkapi dengan studi literatur yang sudah dipaparkan pada bab-bab sebelumnya, dapat disimpulkan bahwa pesan utama dari lirik lagu yang berjudul "Secret" karya Hamasaki Ayumi adalah mengungkap sebuah keinginan yang tidak diketahui publik, yakni keinginan akan kebebasan dalam hidupnya. Sang pengarang yang kebetulan adalah penyanyi yang melantunkan lirik lagunya, adalah artis penyanyi wanita Jepang yang sangat terkenal pada era akhir tahun 1990-an sampai dengan awal tahun 2010-an. Di balik kehidupannya yang menjadi idaman orang banyak, ternyata ia justru memimpikan kehidupan sebagai orang biasa. la tidak mempunyai kebebasan karena hidupnya seolah sudah menjadi milik publik.

Simpulan tentang matriks keinginan akan kebebasan diperoleh setelah melalui analisis semiotika puisi dari Riffaterre. Melalui tahap-tahap pembacaan heuristik, hermeneutika, analisis ketidaklangsungan makna, identifikasi dan analisis matriks, model, dan varian, serta kajian interteks terhadap hipogram dari penulisan lirik lagu, peneliti dapat menyimpulkan pesan utama atau makna dari lirik lagu "Secret" karya Hamasaki Ayumi. Matriks tentang keinginan untuk bebas tersebut ditransformasikan dalam model seperti kata dan frasa jiyuuna hane 'sayap kebebasan', tsubasa 'sayap', tobu 'terbang', dan hoshii mono 'keinginan'. Kemudian dari model-model tersebut dijabarkan varian tentang rasa iri pengarang kepada para penggemar atau orang biasa yang bisa bebas, tentang keadaannya yang berada pada kegelapan yang tidak bisa mencapai tempat terang, tentang ketidakberaniannya dalam menghentikan kepakan sayapnya, dan tentang perasaan pesimisnya terhadap keinginannya. 
Dewanti, Y. F., (2021). The Hidden Meaning in Hamasaki Ayumi's "Secret" Song Lyrics based on Riffaterre's Semiotics Analysis. Japanese Research on Linguistics, Literature, and Culture 4 (1), 16-34. https://doi.org/10.33633/jr.v4i1.5435

\section{Referensi}

Grice, P. (1975). Logic and Conversation. In Syntax and Semantics (Vol. 3, pp. 41-58). https://doi.org/10.1111/j.1365-2664.2006.01229.x

Hoed, B. H. (2011). Semiotik dan Dinamika Sosial Budaya. Komunitas Bambu.

https://ayumihamasaki. fandom.com/wiki/Secret_Album. (n.d.).

Kövecses, Z. (2010). Metaphor: A Practical Introduction. English Linguistics / Journal of the English Linguistic Society of Japan, 22(1), 205-231. https://doi.org/10.1023/A:1023919116538

Lakoff, G., \& Johnson, M. (1980). Metaphors We Live by. The University of Chicago Press.

Nöth, W. (1990). Handbook of Semiotics Advances in Semiotics. Indiana University Press.

Noviana, F., \& Saifudin, A. (2020). Pemaknaan Lirik Lagu Shabondama Karya Ujo Noguchi Berdasarkan Analisis Semiotika Michael Riffaterre. Japanese Research on Linguistics, Literature, and Culture, 2(2), 143-160. https://doi.org/10.33633/jr.v2i2.3978

Noviana, F., \& Saifudin, A. (2021). Conceptual Metaphors of "water" in Javanese Proverbs from a Cognitive Linguistic Perspective. In T. R. Soeprobowati, B. Warsito, \& T. Triadi Putranto (Eds.), E3S Web of Conferences (Vol. 317, p. 02014). EDP Sciences. https://doi.org/10.1051/E3SCONF/202131702014

Pradopo, R. D. (1999). Teori, Metode, dan Penerapannya dalam Pemaknaan Sastra. Humaniora, 10, 76-84.

Pradopo, R. D. (2017). Pengkajian Puisi. Gadjah Mada University Press.

Riffaterre, M. (1978). Semiotics of Poetry. Indiana University Press.

Riffaterre, M. (1983). Text Production. Columbia University Press.

Saifudin, A. (2012). Metafora dalam Lirik Lagu Kokoro no Tomo Karya Itsuwa Mayumi. https://doi.org/10.5281/ZENODO.2631232

Saifudin, A. (2018). Konseptualisasi Citra Hara 'Perut' dalam Idiom Bahasa Jepang. Japanese Research on Linguistics, Literature, and Culture, 1(1), 65-78. https://doi.org/10.33633/jr.v1i1.2130

Santosa, P. (1993). Ancangan Semiotika dan Pengkajian Susastra. Angkasa.

Santoso, B., \& Wahyuningsih, T. M. (2019). Analisis Semiotika Puisi Yogorecchimatta Kanashimini Karya Nakahara Chuya. Japanese Research on Linguistics, Literature, and Culture, 1(2), 154-166. https://doi.org/10.33633/jr.v1i2.2501

Semi, M. A. (1993). Anatomi Sastra. Angkasa Raya. 
Dewanti, Y. F., (2021). The Hidden Meaning in Hamasaki Ayumi's "Secret" Song Lyrics based on Riffaterre's Semiotics Analysis. Japanese Research on Linguistics, Literature, and Culture 4 (1), 16-34. https://doi.org/10.33633/jr.v4i1.5435

Swasono, R. N., \& Saifudin, A. (2013). Makna Idiom Hana dalam Perspektif Budaya Orang Jepang. Simposium Nasional ASJI, 1-15.

Teeuw, A. (1984). Sastra dan Ilmu Sastra. Pengantar Teori Sastra. Jakarta: PT Dunia Pustaka Jaya.

Van Zoest, A. (1993). Semiotika: Tentang Tanda, Cara Kerjanya dan Apa yang Kita Lakukan dengannya. Diterjemahkan oleh Soekowati, A. Yayasan Sumber Agung. 